\title{
Immunohistochemistry Study in Normally Calved Postpartum Dairy Cows
}

\author{
S. Alagar*, M. Selvaraju and R. Ezakial Napolean \\ Department of Veterinary Gynaecology and Obstetrics, Veterinary College and Research \\ Institute, Namakkal - 2, Tamil Nadu, India \\ *Corresponding author
}

\begin{tabular}{|c|c|}
\hline & A B S T R A C T \\
\hline $\begin{array}{l}\text { Crossbred cows, } \\
\text { Endometrial tissue, } \\
\text { Postpartum (PP), } \\
\text { Immunohisto- } \\
\text { chemistry. }\end{array}$ & $\begin{array}{l}\text { The puerperal uterine soundness is essential for the re-establishment of postpartum ovarian } \\
\text { cyclicity and next pregnancy. Normally calved } 36 \text { healthy Holstein Friesian crossbred } \\
\text { cows aged between } 2^{\text {nd }} \text { and } 5^{\text {th }} \text { lactations were selected immediately after parturition. Day } \\
\text { of parturition was considered as day } 0 \text { of the experiment. All the selected cows were } \\
\text { randomly and equally divided into } 4 \text { experimental groups viz., group I, II, III and IV } \\
\text { (control). The endometrial tissue collected on day } 10 \text { and } 30 \text { postpartum in all the four } \\
\text { groups through Albuchins's biopsy catheter was processed by paraffin technique and }\end{array}$ \\
\hline Article Info & $\begin{array}{l}\text { sections were cut and mounted on coated slides for immunohistochemistry. These slides } \\
\text { were tested for immunological expression of } C D 3+\text { and } C D 20+\text { cells to identify } T \text { and } B\end{array}$ \\
\hline $\begin{array}{l}\text { Accepted: } \\
\text { 20 September } 2017 \\
\text { Available Online: } \\
10 \text { November } 2017\end{array}$ & $\begin{array}{l}\text { lymphocytes. Immunohistochemistry of endometrium showed mild expression for CD } 20+ \\
\text { cells in groups I, II and III and moderate expression of CD20 +ve cells in control cows on } \\
\text { day } 10 \text { and } 30 \text { postpartum. None of the cows in experimental and control groups expressed } \\
\text { positive for CD } 3+\text { cells. }\end{array}$ \\
\hline
\end{tabular}

\section{Introduction}

Sato (1998) recorded the decreased values of $\mathrm{T}$ lymphocyte proliferative activity on mitogen activation and cytotoxic activity of $\mathrm{K}$ and NK cells. Moreover, the decline of IgG, $\operatorname{Ig} \mathrm{A}$ and $\operatorname{IgM}$ in the blood serum was found (Amino et al., 1978). These changes in the immunological parameters were detected during the postpartum period in cows suffering from mastitis and metritis (Sato et al., 1995 and Sato, 1998).

In cows with prolonged uterine involution time, a significant decrease in the absolute number of lymphocytes and CD2+, CD4+ and CD8+ $\mathrm{T}$ cells on days 7, 14 and 21 after parturition was detected (Levkut et al., 2002).
Immunohistochemistry is used to confirm the identity of the immune cell types present in the endometrium. Positive immune-staining was detected for tyrosine protein phosphatase non-receptor type substrate 1 (CD172A, representing macrophages and granulocytes), CD14 cell surface antigen (a macrophage marker), CD2 molecule (T-cell and natural killer (NK) cell marker) and T-cell surface glycoprotein CD8 (Uthai et al., 2013).

Lower percentage of $\mathrm{T}$ lymphocytes and decreased CD2, CD4 and CD8 subsets of T lymphocytes were observed in the peripheral blood of healthy cows (Van Kampen and Mallard, 1997). CD8+ T lymphocytes are 
mainly of a cytotoxic nature during mid to late lactation, but they are mainly suppressive in postpartum animals.

A decrease in $\mathrm{CD} 2+, \mathrm{CD} 4+$ and $\mathrm{CD} 8+\mathrm{T}$ lymphocytes on 7 days after parturition, but subpopulations were observed (ShaferWeaver and Sordillo, 1997).

Immunohistochemical studies of chronic endometritis biopsies revealed more number of CD3 positive cells (pan T lymphocytes) in stratum compactum.

Six chronic endometritis biopsies revealed CD138 positive cells (plasma cells) in endometrial stroma (Samatha et al., 2013).

Endometritis is mediated by presence of $\mathrm{T}$ and B lymphocytes and plasma cells. Although bovine endometrium supported large number of immune cells, the diagnosis of chronic endometritis depends upon detection of plasma cells within inflammatory infiltrate in endometrium (Crum et al., 1983 and Garner et al., 2004).

Tawfik et al., (1996) observed increase in CD20 positive cells and CD3 positive cells up to 50 and 3 folds respectively in endometritis cases. No difference in number of $T$ lymphocytes in normal and endometritis cases was reported by Disep et al., (2004).

\section{Immunohistochemistry of Endometrium}

The endometrial tissue collected on day 10 and 30 postpartum in all the four groups through Albuchins's biopsy catheter was processed by paraffin technique and sections were cut and mounted on coated slides for immunohistochemistry.

These slides were tested for immunological expression of CD3+ and CD20+ cells to identify $\mathrm{T}$ and $\mathrm{B}$ lymphocytes, respectively in the endometrium by employing polymeric method using $\mathrm{T}$ and $\mathrm{B}$ lymphocytes antibodies as described by Samatha et al., (2013).

\section{Materials and Methods}

Normally calved 36 healthy Holstein Friesian crossbred cows aged between $2^{\text {nd }}$ and $5^{\text {th }}$ lactations were selected immediately after parturition. Day of parturition was considered as day 0 of the experiment. All the selected cows were randomly and equally divided into 4 experimental groups viz., group I, II, III and IV (control). Therefore each group consisted of 9 cows. On day 2 postpartum, cows of group I,II,III and IV were treated with an intramuscular injection of $25 \mathrm{mg} \mathrm{PGF}_{2} \alpha$ (Dinoprost Tromethamine, 5ml, Lutalyse $^{\circledR}$,Pfizer Animal Health India Ltd, India),50 IU oxytocin (10 ml, Syntophar ${ }^{\circledR}$, Interphar Healthcare Pvt. Ltd., Chandigarh, India), $5 \mathrm{mg}$ methylergometrinemaleate $(5 \mathrm{ml}$, Utrasafe $^{\circledR}$, Vet Mankind, New Delhi, India) and $5 \mathrm{ml}$ normal saline (Parental drugs (India) limited, Indore, Madhya Pradesh, India), respectively.

\section{Results and Discussion}

In uterotonics treated groups such as groups I, II and III, there was a mild expression for CD 20 positive cells (B Lymphocytes). Whereas none of the cow in experimental and control groups expressed positive for CD3 positive cells (T Lymphocytes). However, there was a moderate expression of CD20 +ve cells on day 10 and 30 postpartum in control cows (Plate 6). The results indicated bacterial infection might have been cleared in all the uterotonic drugs treated cows. Further no expression of CD3 +ve cells in control and experimental cows confirmed the absence of cytotoxic immunity due to viral infection in these cows. 


\section{Plate 6}

\section{Immunohistochemistry of endometrium}

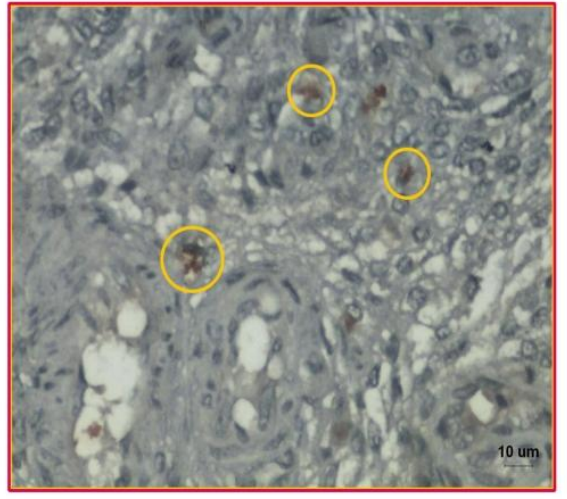

Expression of CD 20+ve cells Group II

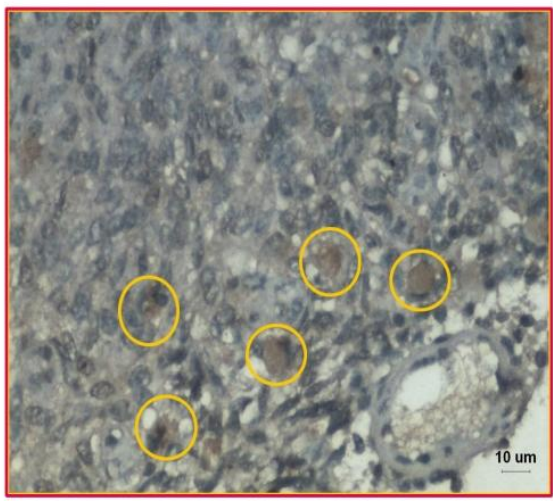

Expression of CD 20+ve cells Group IV

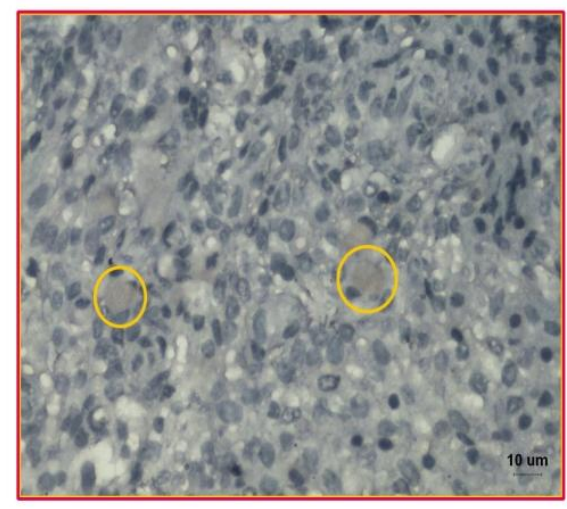

Expression of CD 20+ve cells Group III

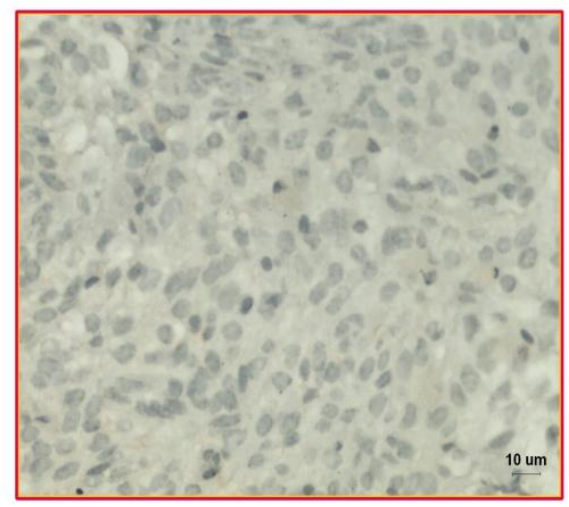

No expression of CD 3+ve cells Group I
In this experiment CD3+ and CD20+ markers were used to assess $\mathrm{T}$ lymphocytes and $\mathrm{B}$ lymphocytes, respectively in the uterine endometrium. In control and treatment groups, there was no expression of CD3+ve cells on day 10 and 30 postpartum. This result concurred with the finding of Samatha et al., (2013) who found more number of D3 +ve cells in stratum compactum of endometritis affected cows. Absence of CD3 +ve cells in all the cows in this investigation indicated no cytotoxic immunity in the uterus. Moderate expression of CD20+ cells in control cows and mild expression in treatment groups of this study were in accordance with the reports of Tawfik et al., (1996) and Disep et al., (2004) in cows. The poor expression of CD20 + ve cells indicated the absence of cell mediated immunity and no clinical bacterial infection in all the cows of treatment groups as described by Tawfik et al., (1996).

The CD20+ ve cells expression were higher in control group followed by groups II, III and I which concurred with the conception rate in each group of the study. 
References

Amino, N., O.Tanisawa, K. Mijai, F. Tanske, C.Hyashi and M. Kawashima, 1978. Changes of serum immunoglobulins $\mathrm{IgG}, \quad \operatorname{Ig} \mathrm{A}, \quad \operatorname{IgM}$ and $\operatorname{IgE}$ during pregnancy. Obst.Gynae., 152: 415-420.

Crum, C.P., K. Eqawa, C.M. Fenoglio and R.M. Richart, 1983. Chronic endometritis, the role of immunohistochemistry in detection of plasma cells. American J. obst. And Gynae., 147: 812-815.

Disep, B., B.A. Innes, H.R. Cochrane, S. Tijani and J.N. Bulmer, 2004. Immunohistochemical characterization of endometrial leucocytes in endometritis. Histopathology, 45: 625-632.

Garner, B., B. Llene, Nickell, A. Jennifere and K. Sohila, 2004. Routine Syndecan1, Immunohistochemistry aids in the diagnosis of chronic endometritis. Archives Path. Lab. Med., 128: 10001003.

Levkut, M., J. Pistl, V. Revajová, J. Choma, M. Levkutová and V. Dávid, 2002. Comparison of immune parameters in cows with normal and prolonged involution time of uterus.Vet. Med., Czech, 47: 277-282.

Samatha, V., C.H. Srilatha, Y.S.R. Anjaneyalu and R.V. Suresh Kumar, 2013. Ultra structural and immunohistochemical studies of endometrial biopsies in repeat breeder buffaloes. Intl. J. Food, Agri. Vet. Sci., pp: 203-206 ISSN: 2277-209X (Online).

Sato, S. 1998. Immunosuppression in periparturient cows and the effects of immunostimulation. Tohoku J. Vet. Clin., 21: 61-70.

Sato, S., T. Suzuki and K.Okada, 1995. Suppression of lymphocyte blastogenesis in cows with puerperal metritis and mastitis. J. Vet. Med. Sci.,57: 373-375.

Shafer-Weaver, K.A. and L.M. Sordillo, 1997. Bovine CD8+ suppressor lymphocytes alter immune responsiveness during the postpartum. Vet. Immunol. Immunopathol., 56: 5364.

Tawfik, O., S. Venuti, S. Brown and J. Collins, 1996.Immunohistochemical characterization of lenkocytic subpopulations in chronic endometritis. Infect. Dis. Obst. Gynae., 4: 287-293.

Uthai, T.S., Q. Chen, S.E. Kirton, M.A. Fenwick, Z. Cheng, J. Patton, A.A. Fouladi-Nashta and D.C. Wathes, 2013. Influence of energy balance on the antimicrobial peptides S100A8 and S100A9 in the endometrium of the postpartum dairy cow. Reprod., 145: 527539.

Van Kampen C. and B.M. Mallard, 1997.Effects of peripartum stress and health on circulating bovine lymphocyte subsets. Vet. Immunol. Immunopathol., 59: 79-91.

\section{How to cite this article:}

Alagar, S., M. Selvaraju and Ezakial Napolean, R. 2017. Immunohistochemistry Study in Normally Calved Postpartum Dairy Cows. Int.J.Curr.Microbiol.App.Sci. 6(11): 2651-2654. doi: https://doi.org/10.20546/ijcmas.2017.611.311 